\title{
URBAN REGENERATION OF PUBLIC SPACE - AL-ALFI STREET - DOWNTOWN CAIRO
}

\author{
S. ATTIA, Z. SHAFIK, A. EL HALAFAWY \& H.A. KHALIL \\ Department of Architecture, Faculty of Engineering, Cairo University, Egypt.
}

\begin{abstract}
Urban regeneration has been an accepted strategy for reviving city centers around the globe in Western Developed settings and in developing cities for decades. In Cairo, post January 25th Revolution, the Egyptian government sought an approach to upgrade several sites in downtown classical Cairo, to set new conditions for use of public space, to redistribute the power of authority and re-define the rules for the claim of public space of the city. The Cairo Governorate officially launched many projects within the same period; mainly focusing on refurbishing squares and streets, facades face lifting, controlling vendors' trespassing and regulating car parking space among other regulations within Downtown area. However, having accepted and acknowledged the governmental intentions of the regeneration projects a question poses itself as to 'How the community perceives and cherishes those initiatives?' More important questions are raised regarding the regeneration of Al Alfi Street, the case study that addresses the governmental attempt in down town Cairo in 2015. It brings to light the dynamics enacted between different stakeholders. A research is conducted by adopting participant observations, surveys, questionnaires, and interviews with the local community and different stakeholders to understand their perception and appreciation to the '2015' urban regeneration attempt. The findings of the paper set the urban regeneration principles in a discussion aiming at assessing the stakeholders' involvement versus their goals and measuring their satisfaction with the outcome of the project, while still posing the question of the meaning of urban regeneration to the local community and to alternative scenarios that could yield more successful outcomes.
\end{abstract}

Keywords: downtown classical cairo, public spaces, right to the city, street vendors, sustainability, urban regeneration.

\section{INTRODUCTION}

This research [1] investigates the concept of urban regeneration through its consecutive transformations. It attempts to relate the concept to the development and interventions in public spaces downtown Cairo. It addresses issues of urban regeneration to public spaces within the current legal, institutional and socio-economic conditions in Cairo. The paper focuses on the regeneration of $\mathrm{Al}$ Alfi Street as a case study and a pilot project; and critically presents and discusses the current trends of urban regeneration implemented in down town Cairo district.

Two approaches of urban regeneration are recognized; the first relates to understanding the city as a self-organized organism where each citizen plays an individual role; whereas the second approach focuses on understanding the city as a Cartesian system, a reasoned construction where citizens follow an organization structure enacted by the society. Different strategies of regeneration address these two poles and take different expressions based on the situation and conditions of every project and its vision. Since Haussmann's Paris and the reconstruction of London, the concepts or urban regeneration oscillated between these approaches; while regeneration attempts varied in 'the size and complexity of the problems, 
the speed of change, and the concomitant scale and sophistication of policy' Couch and Fraser [2].

The paper focuses the discussion on the Cairo context, in general, and the succession of policies and strategies that developed in the public realm with specific mention to the changes in policies that evolved during and after the 25th of January revolution to the present time. The discussion focuses on the projects of downtown area as the paper's principle domain.

\section{URBAN REGENERATION: THE PROCESS AND THE PRODUCT}

When urban regeneration is mentioned, it is usually associated with development taking place in cities Tallon [3]. Tallon [3] elaborates more explaining that it is a component of the urban policy. He confirms the statement of Turok [4] that urban regeneration is a process that involves the community. Roberts [5] in his famous Handbook states that regeneration involves stakeholders including the private, public, community, and voluntary sectors. The process is not only focused around participation, but also about the integration of other processes including social, economic and environmental shift in the area of intervention. It is an integrated vision to develop and manage what the spaces have lost Roberts [5]. In fact, urban regeneration is about managing the human and physical resources to create better sustainable communities. Urban regeneration is also associated with revitalization of the city center and its surroundings Barnett [6]. Being in a continuous state of transformation the city is always in search for a balance between the built environment, the emerging need of its inhabitants, and most of all, the adaptive use of its public space. As a product, urban regeneration has an important role in promoting the city image and the public realm. In fact, as Bianchini [7] states, it evolved from a socio-economic politically supported scheme to include the cultural policy parameters.

To ensure that urban regeneration delivers a sustainable product, many charters were issued for cities, or regions around the globe. In 2007, the EU - LEIPZIG CHARTER on Sustainable European Cities addressed indirectly the regeneration process through the sustainable integrated development [8]. While The Toledo Declaration sets out urban integration regeneration in 2010, more precisely urban integration regeneration [9].Other focused charters were developed. The example of the sustainability Charter ISIS [10] delivers schemes for urban regeneration, along with environmental sustainability and waterside urban design concepts. The urban regeneration theme includes/discusses location and connectivity, contextual analysis, stakeholder engagement, neighborhoods, community and stewardship and economic diversity and independence.

\section{URBAN REGENERATION IN THE CAIRENE DOWNTOWN CONTEXT}

In Cairo, urban initiatives started their early phases by the end of the last century. Downtown, known as Khedival Cairo, is one of the most prestigious valuable historic areas in Greater Cairo Region. El Kadi [11] describes its morphology and typology spotting the wealth and richness of the area with its buildings, passageways, and squares. Despite its primary location, and historical background, the Khedival Cairo went through multiple processes of degradation and revitalization alternatively. Among the earliest urban interventions in downtown Cairo were several rehabilitation projects in different sites aiming at changing vehicular streets to pedestrian malls, namely El Alfi site; El Borsa area and Shawarby Street. Al Alfi pilot project was initiated and carried out by Cairo Governorate in 1997. The work included paving roads, installing basic street furniture and cleaning up building frontages; at this stage, the project had no clear positive impact on the socio-economic level, participation was absent, 
and the stakeholders were left behind any decision-making or involvement in the process. The traffic restrictions were not much appreciated, but in the meantime, commercial activities changed to match with the pedestrian street.

The second project was located in El Borsa. It included financial institution buildings (the Stock Exchange, Central Bank, National Bank, Suez Canal Bank), the Cosmopolitan Hotel, built in 1903, the National Radio station, as well as, a substantial number of commercial and residential buildings, many dating back to the 1920s and 1930s. The Stock Exchange was the focal building designed in 1928. The project was initiated in 1999 by the Secretary of State for Governmental Affairs and was achieved by private sector funding supplied by consulting firms, entrepreneurs and businessmen and the Egyptian Stock Exchange. The regeneration work included paving streets; creating parks, planting palm trees, installing urban furniture, cleaning up and color-coordinating building frontages [12]. Being at a larger scale, it was considered a flagship project, since it involved the private sector, before and after the process. The nature and source of funding was diversifying for safeguarding the heritage and improving the quality of life and delegating the responsibility of regeneration to the entire community of stakeholders. These pioneer projects may well concern a fraction of the population; however, their benefit lies in communicating the relevance of regeneration to a more extensive community. The final success or failure of the projects depended on the appreciation and interaction of all user groups with the projects. In general, $\mathrm{Al}$ alfi project was not perceived as successful as El Borsa by residents, shop owners, workers and casual users; who agreed that the overall quality of the environment had considerably improved HERCOMANES [13]. Other projects followed in Islamic Cairo, and for two decades, regeneration projects were limited.

\section{SETTING THE SCENE FOR URBAN REGENERATION IN DOWNTOWN CAIRO}

The (Law 144/2006) issued in 2006, marks the first management tool for conservation of valuable buildings downtown Cairo, valorizing its architectural assets in order to attract residents and investors. The cooperation of both Cairo Governorate and the National Organization for Urban Harmony (NOUH) has resulted in the restoration of buildings along major arteries in the area. In parallel, the foundation of a private real estate investment company, Al Ismailia, with a capital of 80 million Egyptian Pounds, marked a new trend in dealing with downtown. The mission statement of the company is renovating the city center in order to attract businesses and affluent residents HERCOMANES [13].

In 2008 Cairo 2050 Vision announces the revitalization of downtown area with the support of businesses and stakeholders such as Insurance Companies, El Ismailia for Real Estate Investment Company, private sector businessmen; Banks Abdelhadi et al. [14]. In 2009, an International competition is launched for the revitalization of Khedival Cairo. Al Alfi Street is back in the spotlight, as it offered a ready pedestrian path option that needed regeneration with it complete parameters, after years of degradation. In 2011, during the January uprising events, vendors who claimed their right to the city invaded the public space downtown Cairo. Misinterpreting the new breeze of democracy, for many including street vendors, it was time to declare Cairo a right to all citizens, thus applying Lefebvre's conception of the rights to the city to access and shape urban space Attia [15]. In Late September 2014, it was decided to clear the streets and squares in Khedival Cairo from all street vendors, and give back the downtown area its lost identity. Since then, and to ensure the sustainability of this decision, the Egyptian Government announced the initiative; 'The state of downtown', launching a national interest for this area. Within this initiative, the prime minister declared the necessity 
of selecting quick wins to support all actions, spreading the idea that downtown will gain back its lost identity.

\section{THE RIGHT TO PUBLIC SPACE}

The realm of public space gained specific relevance in Egypt in the past five years; which impacted a change in the urban regeneration policy witnessed after the January 2011 events, indicating a new vision for urban regeneration on behalf of the government. This new trend emerged in response to the events of the 25th of January revolution. In fact, the streets of Egypt witnessed an unprecedented occupation by all types and forms of citizens; particularly persistent was the occupation of vendors to the streets of downtown Cairo area. The occupation of public space represented a situation that could be closely described by Henri Lefebvre as a collective act of claiming the city's urban space as a representative of claiming all human rights of the city inhabitants Lefebvre [16]. The concept of the right to the city', which is based on the assumption that the city is a form of collective artwork to which everybody actively contributes, was experienced in the streets of downtown Cairo.

Purcell [17] argues that Lefebvre's conception of the Right to the City is about: firstly, the right to participation: the right of inhabitants to take a central role in decision-making processes surrounding the production of urban space at any scale; and secondly, the right to appropriate urban space, that should be produced in such a way as to enable the 'full and complete use' of urban space by inhabitants in their everyday lives. It therefore includes the 'right to live in, play in, work in, represent, characterize and occupy urban space... '. Purcell [18] adds that the conceptions of Lefebvre stand against the conception of urban space as private property, or as a commodity to be valorised by the capitalist production process Purcell [18]. Accordingly, the value of the public space as a social realm for inhabitants' interaction exceeds its value as a commodity to be utilized. Purcell [19] argues also that the Right to the city represents a tool for resistance to rethink social relations of capitalism, the spatial structure of the city and the assumptions of liberal democracy. In the situation of a revolution, the resistance does not only aspire to rethink but to inflict change on the situation. The right to the city is about new visions and methods of decision-making and participation that aim at altering the urban/political status; its goal is to change Harvey [20]. Harvey [20] also emphasizes that the right to the city offers all inhabitants the possibility to participate in public life; it results in a new form of a city that represents a collective political interest realized by a collective political will where the public space becomes the stage for inflicting political change.

The social and political interpretations to the concept of the 'Right to the City' capture the essence of the streets of downtown Cairo after the 25th of January 2011. For a long and sustainable period of time images of occupied urban space materialized continuously urging for change.

Deterioration and damage caused by the street vendors in downtown Cairo led to several attempts to find a sustainable solution to relocate them out of downtown Cairo. In September 2012, vendors were moved from the streets of downtown to the historical Azbakeya Park that caused irreversible damage to the park. This was followed by suggestions for compensating them with a one-day open market. A trial for a forced eviction in Giza square led to collisions between authorities and vendors in 2012 resulting in injuries. This situation continued till August 2014, when street vendors' invasion to downtown Cairo was terminated, by their temporarily relocation to the parking lot at Torgoman bus station until a permanent move to Wabur El-Talag site Kafafy [21]. 
It was obvious to many that the crack down on vendors that swarmed the streets of down town classical Cairo was a conscious political step to restore the power back into the grip of the State exemplified in the local governorate. Talaat Harb Street; Tahrir Square and Ramses Square had to become vendor free. Trespassing posed a threat to the authority that struggled to re-establish its control over vendors, graffiti and protestors who stir unrest significant of the revolution years, from 2011 until 2013. The campaign 'to clean up downtown Cairo is an urban demonstration of the reassertion of the State in the public space. It is an attempt to clear whatever is considered a threat to its image,' Malsin [22]. Attempts of gaining control of the city included relocating vendors; banning tuktok as a mode of transportation; repainting facades of strategically located buildings overlooking downtown squares; landscaping main squares such as Tahrir. Several regeneration projects took place in downtown Cairo specifically in El Alfi Street, Orabi Square; El Shawarby street, Saraya El Azbakeyia Street, and Koddak Passage. Restoring order to downtown public space passed under the umbrella of urban regeneration. Many Activists call this an attempt to create an 'apolitical / revolutionfree down town' Malsin [22]

The dilemma lies in the inability to dispense of vendors and abolish informal street activities completely or even selectively in certain locations. It is estimated that the informal economy represented partly in street vending; among other informal forms; constitutes about $30 \%$ of the country's economy which also employs $40 \%$ of the labour force based on the Ministry of finance declarations. Dealing with the intricacies of this dilemma is exemplified in the case study of the Al Alfi Street, where Cairo Governorate devised a mechanism of control and management of illegal street vending that sustains the economies of the situation and its related benefits while placing it in the grip of official authorities.

\section{PUBLIC OPEN SPACE AS A DOMAIN FOR URBAN REGENERATION}

Public space development is an intrinsic facet of successful urban regeneration policies. It is utilized as a realm to improve the environment, to enhance urban images, and to improve the quality of life for urban dwellers. When dealing with cities, the simple application of urban regeneration means using public space as the key for successful interventions Okabe [23]. Accordingly, this research adapts a definition for urban regeneration of public space as follow:

'It is the process of enhancement of the citizenship in a sustainable environment. It stems from integrated vision that includes economic, physical, social and environemental aspects and improves the quality of life. It is the best way to revive the city centre and an essential precondition for the locality and acts as a catalyst for the city as a whole.'

AbdElalim [24] postulates that urban regeneration of public spaces issues could be tackled according to three main levels. The first level focuses on the development of open space throughout different time periods, sets its typology and analyses its functions. The second level emphasizes the role of governmental and non-governmental organizations in developing the quality of urban space. It deals also with the concept of community perception and use of space. In this level, the space is considered an effective tool forming and developing the urban context around it. The third level tackles the social and cultural aspects and provides, on one hand, methods and tools to understand the relationship between social and human aspects and the morphology of open space; and on the other hand, suggests programs and frameworks for activating the social and cultural content of public space. A fourth level 
should be mentioned that relates public space to implementation: Laws and legislations, which play an important and main role in the regeneration of public space, especially in the initiatives of the government.

In addition, different governmental agencies and authorities, such as the parliament, the President, Prime Minister or the Ministry of Antiquities, issue ministerial decrees affecting public space. Moreover, general and detailed plans are proposed by the General organization for physical planning, GOPP. In addition, recommendations of committees responsible for listing historical sites and buildings of heritage value in some Egyptian cities are mandatory. It is also vital to mention that downtown Cairo is considered a setting of valuable architectural heritage, thus it falls under the jurisdiction of NOUH.

The involvement of many governmental actors without strong coordination, led to the lack of effectiveness in applying and following up laws and decrees, and affected the participation of the private sector. 'There are many barriers to engaging the private sector in regeneration activity and as such, the public sector plays a crucial role in identifying suitable opportunities that will be attractive both economically and socially to potential private sector partners,' Trebeck [25].

\section{EL ALFI CASE-STUDY}

\subsection{History of El Alfi Street}

El Alfi street is located in the downtown commercial area joining Orabi Square with Azbakeya gardens passing by Emad ElDin Street. This old neighborhood was established during the opening of the Suez Canal Hawas [26]. The entire downtown area reached its climax in 1907 witnessing foreigner and elite investments in buildings and squares. El Alfi Street was originally an old hub for nightlife and casinos in the 1920s favoured by European visitors seeking entertainment. In the 1930s the locals transfered their apartments into offices since downtown was becoming a prestigeous area. Commercial activities were also introduced changing the area into a mixed-use district Abdelhadi et al. [14]. In 1956 and after the July revolution the emigration of the expatriates who were replaced by middle income Egyptians left the area with negative impact; urban deterioration and neglect contributed to the continuous move of the residential community out of downtown area and its replacement with commercial use Abdelhadi et al. [14]. From 1976 to 20061.5 million resident left downtown causing its contiounal deterioration.

El Alfi Street is 20 meters wide and 150 meters long accomodating buildings with heights varying from 2 to 3 storeys and 3 to 4 storeys high, at the ends of the street taller buildings are located overlooking Orabi Square and Emad ElDin street. The urban space is determined by the ratio between the width of the street and the 3 storeys high buildings creating a significant urban enclosure that is shaded and at the same time naturally illuminated. El Alfi is mostly occupied by commercial businesses at the ground floor level with more than 50 stores distributed along the street which offer various services and merchandize. The activities are dominated by restaurants, food kiosks with many sidewalk cafes, highlighted by Aakher Sa'a restaurant. Shops selling electric merchandize and car spare parts are widely spread in the district; other shops cater on the local community include a pharmacey, a print shop, and a stationery. The commercial services are coupled with entertainment services exemplified by Shahrazad night club and a cinema which perpetuate the original entertainment activity of El Alfi. 


\subsection{Urban regeneration project}

El Alfi Street was transfered from a vehicular street to a pedestrian mall in 1997; traffic was banned and an urban space became available to the community giving the locals a chance to appropriate the city which naturally resulted in trespassing behavior. The pedestrian project did not incorporate upgrading efforts; it basically made an urban space available to the public. Having gone through the first attempt of urban regeneration, the government decided to make a second regeneration attempt in 2014.

The government announced the regeneration of down town. Workshops and meetings between partners from governmental bodies, academia, private sector, stakeholders and other partners were held. Figure 1 shows the street before and after intervention.

Examining the interactions between the different stakeholders in the regeneration projects, it was found that Al Alfi Street is the most suitable case study for testing regeneration principles based upon the Cabinet and Cairo Governorate.

Decision to clear downtown area from peddlers. Works on site extended from Orabi Square till Emad El Din Street, along El Alfi street emphasising on painting building facades overlooking Al Alfi Street, removal of stores signages, replacing the damaged street furniture with new designed ones, upgrading entire street pavement with homogenous design, applying infrastructure works and piping, and installing flower pots without planting trees Several meetings were held weekly organised by Cairo Governorate, headed by the Governor and attended by representatives from the Governorate, local authorities and experts from different organizations and institutions.

\subsection{The stakeholders}

The regeneration project was initiated by Cairo Governorate, the owner of El Alfi Street, while mobilizing different stakeholders to participate in the project each with a specific role.
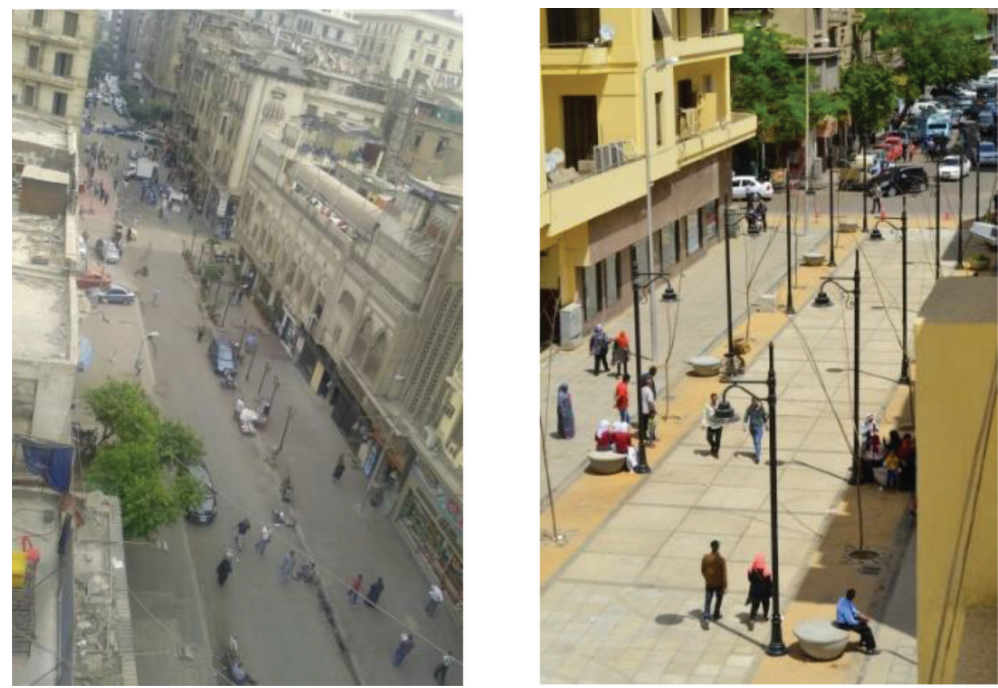

Figure 1: Alfy street before and after refurbishment. 
Cairo Governorate, GOPP and NOUH represented the governmental institutions involved in the project; who were responsible for issuing legislations and making all decisions regarding design aspects of the regeneration project. Other stakeholders funded the project namely Ismailia Company upgrading its owned property. Misr Real Estate assets part of Misr Insurance holding Company sponsored the painting of buildings' facades based on the approved design. Private owners of businesses and shop owners had to adjust their shop frontages based on the agreed upon design.

Other involved stakeholders included the consultant, the review committee and the governorate advisors of academicians and professionals, and the contractor. Researchers and postgraduate students were involved in conducting before and after surveys. Finally, Social Media Companies were responsible to bring the project to the local community awareness.

\subsection{Process and solutions}

Following up in 2014 on the social profile of the residential community in El Alfi district, the involved research team used the same distribution of the residential sample tracking back residents who participated in the 2001 Hercomanes survey. Out of the 8 households, only 3 families still lived in El Alfi, the rest of the residents moved out. Through the survey process before the renovation, the inhabitants, shop owners, and peddlers as well were asked about their feelings towards the 1997 pedestrian project, their aspiration, solutions and willingness to participate. Interviews reveal that complaints were directed to the wooden benches whereas most of the shop owners in El Alfi Street complained about seats attracting homeless people and encouraging delinquent attitudes of young lovers. The owners of the cafes deliberately destroyed the public benches for their own benefit to place their own seats and rent them to passers-by. Many locals were concerned about security, cleaniness, maintenance, and frequent supervision of the project.

\subsection{Evaluation and assessment}

The response of the Alfi community to the regeneration project was assessed through a field survey, where questionnaires, interviews and observations were conducted to understand the locals' assessment to the project. 23 shop owners were interviewed, among which 17 were either employers or shop owners in Al Alfi itself, the remaining 6 were in the adjacent street $\mathrm{Al}$ Azbakeya. The interviews were carried with the same sample during and after the process. The findings during the process indicate that $10.5 \%$ of the informants were dissatisfied with the regeneration project, $21.5 \%$ were neutral about it, and $68 \%$ were satisfied with the expected project outcome. After the process, $4 \%$ were disatisfied, $4 \%$ were neutral, $52 \%$ stated its is quite good and acceptable, while 35\% thought it could be rated as excellent initiative. The outcome of the field survey yielded the following findings:

- The coffee shops' tables still occupy the street leaving only the intermediate space between the buildings ( 6 meters) for pedestrian activity which is always infringed upon from the coffee shops.

- In front of Nile stock store, some peddlers use it as a coffee shop space without owning a place; they just rent the space from the governorate.

- Although the public space should be left for the utilization of the locals, nevertheless, the spot located in front of each store is rented by the governorate. Each store pays 
50 L.E./m2 to reserve this spot and use it for display or pay 25 L.E./m2 just to reserve it without using it; otherwise the governorate reserves the right to rent it to anyone who is ready to pay its rent. Any vendor can officially lease the sidewalk from the governorate even if he does not have a shop on the Alfi Street.

- The peddlers returned to the street intensively specially after the sunset. The seats are now used as display area for the peddlers' merchandize.

- There is no trees in Orabi Square, which make it almost impossible for passersby to sit in it. Some of the pedestrians using the street said that the street is better after removing the green area in Orabi Square, which was a place for the homeless, peddlers and immoral activities.

- There is no security in the street, which also leads to fights between owners about who has the right to use the space.

- The shops owners see that the regeneration project primarily benefits the coffee shops.

- All the shops' owners stated that there were no committees nor occupants representatives meeting with the governorate to coordinate the decision-making and issues concerning El Alfi Street.

- The general assessment of the local community was that the overall quality of the street improved at least in terms of cleaniness of the public space nevertheless the poor quality of the used material meant that the upgrading will not be durable and that the regenration will not last long; starting with the basalt flooring of Orabi Square was broken in several parts of the square and was not repaired. The most obvious change is the renovation of elevations from the pedestrians' point of view.

\section{CONCLUSION}

The regeneration project of El Alfi Street was initiated with the objective of controlling a situation of chaotic trespassing. The public space was almost entirely lost to the appropriation of the vendors. In an attempt to regain the power of the State, the regeneration projects provided a feasible approach and a promising solution to restore order in the public space. The project ended with re-establishing the control of the state over public space by issuing legislations to the act of trespassing; presently citizens can trespass after taking the permission of the authorities and after paying the price of occupying the public space to the government. By such agreement between the players of the public realm, the inhabitant gave up the right to public space, which officially belongs to the government. The right to public space requires the presence of confrontation and collision between different interest groups; but such confrontation does not exist after the agreement was reached between the authorities and the locals about whose right was the public space of the city.

Although the launching of the project was announced by the governor in the street, the locals felt that they were not part of the decision-making, nor were they aware of the process before hand; nor were they informed about it in due time to allow any form of effective participation. Having limited resources, it became feasible for the government to carry the responsibility of planning, funding and subsequently controlling the process, while the public has to conform to the rules and regulations issued by the governorate and the local authorities. Although the interventions in the street focused on physical aspects without anticipating economic implications, and how it will be sustained, it represents the base of a sequence of street interventions in downtown, spreading awareness, and generating a new interest among citizens about the importance of the esthetical, historical, cultural and economic values downtown that deserve to be conserved and revitalized. 


\section{REFERENCES}

[1] This paper is developed throughout a joint Egyptian-French project funded by the STDF (Science and Technology Development Fund), Egypt.

[2] Couch, C. \& Fraser, C., Introduction. Urban Regeneration in Europe, eds. C. Couch, C. Fraser \& S. Percy, Blackwell Publishing: Oxford, pp. 1-16, 2003. http://dx.doi.org/10.1002/9780470690604

[3] Tallon, A., Urban Regeneration in the UK, 2nd edn., Routledge, 2013.

[4] Turok, I., Urban regeneration: what can be done and what should be avoided? Istanbul 2004 International Urban Regeneration Symposium: Workshop of Kucukcekmece District, Kucukcekmece Municipality Publication: Istanbul, pp. 57-62, 2005.

[5] Roberts, P., The evolution, definition and purpose of urban regeneration, Urban Regeneration: A Handbook, eds. P. Roberts \& H. Sykes, Sage Publications in association with the British Urban Regeneration Association: London, pp. 9-36, 2000.

[6] Barnett, J., The Elusive City, Harper and Row: New York, 1986.

[7] Bianchini, F. \& Parkinson, M. (eds), Cultural Policy and Urban Regeneration: The Western European Experience, Manchester University Press: Europe, 1993.

[8] Ministers Responsible for Urban Development in the EU, Leipzig Charter on Sustainable European cities, May 2, 2007, Approved at the Informal Council held in Leipzig on 24, 25 May 2007.

[9] Informal Ministerial Meeting on Urban Development (2010) Toledo Declaration, held in Toledo, 2010.

[10] ISIS Waterside Regeneration Sustainability Charter, January 2013.

[11] El Kadi, G., Le Caire Centre en Movement, Institut de Recherché pour le Développement: Marseilles, 2012.

[12] Department of Architecture at Cairo University \& IRD, Regenerating Public Space in Central Cairo, Joint research, Third Report, Cairo, 2015.

[13] HERCOMANES: Institut de Recherche et D'etudes sur la Mediterranee et le MoyenOrient (GREMMO), InstituoUniversitario di Architettura di Venizia, Faculty of Architectural Engineering at the University of Aleppo \& the Centre for Architectural and Engineering Support at Cairo University, Heritage Conservation \& Management in Egypt and Syria "HERCOMANES", 2000-2003 Project Report, Cairo University, 2003.

[14] Abdelhadi, A., El Nachar, E. \& Safeieldin, H., Pedestrian Street Life in Historic Cairo Authenticity and Counterfeit, Revitalising Built Environments: Requalifying Old Places for New Uses Proceedings, International IAPS-CSBE \& Housing Network, 2009.

[15] Attia, S., Revitalization of Downtown as Center for Social Democracy and Sustainable Growth, Ecocity Summit Book Library, 2012.

[16] Lefebvre, H., La Droite a la Ville, Anthropos: Paris, 1967.

[17] Purcell, M., Excavating lefebvre; the right to the city and its urban politics of the inhabitant. GeoJournal, 58(3), pp. 99-108, 2002. http://dx.doi.org/10.1023/B:GEJO.0000010829.62237.8f

[18] Purcell, M., Citizenship and the right to the global city: reimagining the capitalist world order. International Journal of Urban and Regional Research, 27(3), pp. 564-590, 2003.

[19] Purcell, M., Recapturing Democracy; Neoliberalization and the Struggle for Alternative Urban Futures, Routledge: London, 2008.

http://dx.doi.org/10.1111/1468-2427.00467 
458 Urban Regeneration and Sustainability

[20] Harvey, D., The right to the city. International Journal of Urban and Regional Research, 27(4), pp. 939-941, 2003.

http://dx.doi.org/10.1111/j.0309-1317.2003.00492.x

[21] Kafafy, N., Right to urban space in post-revolution cairo: a study for street vending phenomenon. Proceedings of Responsive Urbanism in Informal Areas International Conference, Towards A Regional Agenda for HABITAT III, Cairo, Egypt, 2014.

[22] Malsin, J., Cairo street traders squeezed out in push to make city 'revolution free'. The Guardian, 2015.

[23] Okabe, A., Reclaiming public space for people: the roots of european urban regeneration, DBJ Research Center on Global Warming, Discussion Paper Series No. 38 (7/2011), Development Bank of Japan: Japan, 2011.

[24] AbdElalim, E., Social balance in urban space: towards a new vision of urban space in Egypt, Unpublished PhD thesis, Cairo University, Faculty of Engineering, 2002.

[25] Trebeck, K., Private sector contribution to regeneration: concepts, actions \& synergies, working paper No.9, Centre for Public Policy \& Regions, 2007.

[26] Hawas, S., Khedivian Cairo - Identification and Documentation of Urban Architecture in downtown Cairo, The Arab Contractors Press: Cairo, 2002. 